Софија А. Биланџија* Јелена К. Костић-Томовић Универзитет у Београду Филолошки факултет
УДК 811.112.2'367.625:811.112.6'367.625

ДОИ https://doi.org/10.18485/analiff.2017.29.2.2

\title{
ПРЕФИКСИ НЕМАЧКОГ ПОРЕКЛА У СКАНДИНАВСКИМ ЈЕЗИЦИМА
}

У раду се анализирају ненаглашени префикси немачког порекла у творби глагола у данском, норвешком и шведском језику. Анализирају се примарно префикси be- i for-/för- иако је број префикса немачког порекла нешто већи (an-, bi-, unn-/und-, veder-, ge-, er-). У раду се анализира порекло наведених префикса (нисконемачки - високонемачки), објашњавају се разлози великог утицаја средњенисконемачког на лексички и творбени фонд скандинавских језика у периоду средњег века. Аутори се потом баве могућностима разграничења од домаћих, нордијских префикса с обзиром на генетску сродност језика, и анализирају могућност анализе великог броја префигираних глагола, јер многе творбене основе немачког порекла у савременом језику често имају статус уникатних морфема. Потом се анализирају заступљеност и продуктивност датих префикса у савременим скандинавским језицима, будући да их карактеришу делимична семантичка и синтаксичка регуларност, али и врло ограничена продуктивност.

Кључне речи: скандинавски језици, немачки језик, префикс, префиксација, творба речи, лексикализација

\section{1. Увод}

Овај рад бави се анализом ненаглашених префикса немачког порекла у творби глаголских лексема у савременим скандинавским језицима: данском (да.), норвешком (но.) и шведском (шв.). У раду ће се пажња посветити неколиким важним аспектима које ова тема обухвата. Један од кључних аспеката је свакако позиција овог релативно

Контакт: Софија Биланџија, Филолошки факултет, Група за скандинавистику, Студентски трг 3, 11000 Београд. E-mail: sofija.bilandzija@fil.bg.ac.rs и sofibi75@gmail.com 
малог броја префикса у систему префиксације савремених скандинавских језика (be-, er-, for-/för-, ge $)^{1}$, посебно уколико се у обзир узме понешто редефинисан инвентар префикса у систему творбе речи у савременом данском, норвешком и шведском језику. У вези са овим се разматра и однос творбеног статуса између оних творбених елемената који се у скандинавистичкој творби речи сматрају префиксима и оних који се сматрају одредбама глаголских сложеница, а све то везано за однос између одвојивих и неодвојивих префикса у немачкој творби. У раду се објашњава порекло наведених префикса и могућност разграничења од домаћих, нордијских префикса, а потом се анализирају њихова заступљеност и продуктивност у савременом језику, те основне претпоставке лексичко-семантичке (категоријалне) и синтаксичке модификације до којих доводе.

С обзиром на то да је реч о префиксацији превасходно глаголских лексема, грађа је ексцерпирана из великих једнојезичних штампаних и електронских речника сва три језика.

\section{2. Инвентар и статус}

Префиксација се у скандинавистичкој творби речи посматра као подтип извођења, и реч је, дакле, о врсти творбе речи код које се афиксална морфема додаје испред творбене основе. Па ипак, и у водећим монографијама посвећеним творби речи и у приручницима постоји одређени степен неслагања у вези са инвентаром префикса. У овом инвентару се осим наведених префикса немачког порекла налази и одређени број страних и домаћих префикса који означавају негацију или пејорацију, али и велики број страних префикса који означавају временске и просторне односе, количину и меру. Афиксни статус и место ових префикса у систему префиксације већ више од две деценије проблематизују се у германистичкој дериватологији у дискусији о тзв. кон-

1 Ово није коначан инвентар префикса немачког порекла у скандинавским језицима. Немачки префикси су и an-, bi-, unn-/und- и veder-. Осим што нису посебно продуктивни, ови префикси су у сва три језика наглашени, а префикси an- и $b i$ - понекад могу да стоје иза глагола, понашајући се као сложен глагол са одвојивом партикулом (уп. angå : gå an, bistå : stå bi). 
фиксима (на пример, bi-, makro-, mikro-, super-, multi-, krypto-, kvasi- и др.) (Fleischer \& Barz, 1992: 25). Осим тога, различити аутори у префиксе убрајају и мањи број префикса домаћег порекла, чији би се статус афикса свакако могао тематизовати у дискусији о прелазним облицима између извођења и слагања с обзиром на њихову форму и аутономност значења (пре свега sam- и gen-/gjen-). Уколико би се из система прототипичне префиксације искључили сви они традиционални префикси са садашњим статусом конфикса, те поменути домаћи префикси, инвентар префикса би се у скандинавским језицима драстично смањио, а префикси немачког порекла би чинили квантитативно значајну категорију, посебно у систему деривације глагола од других глагола.

Префикси који се у скандинавским језицима недвосмислено могу идентификовати као префикси немачког порекла се, у оној мери у којој се може постулирати било каква продуктивност, углавном везују за деривацију глаголских лексема, а ређе за деривацију именица и придева (уп. и SAG II: 517). У систему глаголске деривације се као специфичност издваја ненайлашености префикса for- (да/но.), одн. för- (шв.) $)^{2}$ и be-, потом ge-, који се нешто ређе тематизује с обзиром на непродуктивност, те $e r$ - у данском и норвешком (у шведском језику је наглашен). Иако је формално реч о префиксима страног порекла, префикси немачког порекла се за разлику од грчких или романских не везују за стране творбене основе, већ за скандинавске. Зато се без обзира на страно порекло веома често у класификацијама разматрају у оквирима јединственог нордијско-германског система (Thorell, 1981: 10-11). Ненаглашеност се у деривацији свих врста речи у скандинавским језицима везује превасходно за префиксе из грчко-романског система, а не за домаће или општегерманске елементе (Elert, 1973: 107). За префиксе be- и for-/ för- се потом постулирају и делимична семантичка и синтаксичка правилност, али и врло ограничена продуктивност (Elert, 1973: 107).

2 У шведском језику префикси $b e-$ и för- могу бити наглашени уколико се нађу испред творбене основе која је фонолошка сложеница. Реч је, дакле, о творбеним основама које су из творбене перпективе или изведенице или нешто ређе нетворенице, али имају распоред нагласака који је карактеристичан за сложенице: јак нагласак на првом творбеном елементу (или код нетворенице на првом слогу) и јак споредни нагласак на другом елементу. Тада префигирани глагол добија тонски акценат 2, јак нагласак на префиксу, и јак споредни се задржава на исходишној позицији (уп. $\left.{ }^{2} f \ddot{r} r-o r, s a k a,{ }^{2} b e-a r, b e t a\right)$. 
Ова супкласа префикса углавном кореспондира са оним префиксима који се у немачкој дериватологији и граматици називају неразgвојним ирефиксима (нем. untrennbare Präfixe, уп. и термин untrennbare Verben), а то су be-, ent-, er-, ge-, ver-, zer- и miss-. Нераздвојни префикси домаћег порекла у немачком језику су такође ненаглашени (Костић-Томовић, 2013: 34-35; Fleischer \& Barz, 1992: 320). Глаголи који би одговарали немачким глаголима са оgвојивим или разgвојним ирефиксима (нем. trennbare Präfixe, уп. и термин trennbare Verben) у скандинавистичкој дериватологији сматрају се без изузетка сложеницама. Овакви глаголи називају се їлайолима са йарииикулом (да. partikelverbum, но. partikkelverb, шв. partikelverb) ${ }^{3}$, при чему се термин партикула јавља као термин под којим се обједињују предлози и прилози од којих партикуле и воде порекло (на пример, да. fremavle, overanstrenge; но. underskrive, inngå; шв. uppge, avskaffa) (о алтернативном тумачењу статуса раздвојних префикса у немачкој дериватологији, те односу раздвојних префикса и хомонимних предлога уп. Костић-Томовић, 2013: 37; Duden, 1995: 449; Duden, 2006).

\section{3. Порекло префикса}

\section{1. Изазови анализе при позајмљивању творбених морфема међу сродним језицима}

Када се у скандинавистичкој дериватологији говори о позајмљивању творбених елемената из других језика, недвосмислен је статус суфикса и префикса који потичу из грчког, латинског и романских је-

3 Аутори граматика и приручника творбе речи сагласни су у оваквом схватању иако глаголи са одвојивим партикулама не испуњавају један од главних критеријума слагања у савременим скандинавским језицима - ортографски критеријум, који налаже да се сложена реч пише спојено. Када се партикула појављује испред глаголске основе, такви глаголи се називају чврстио сложеним ілаїолима (да. fast sammensatte verber, но. fast sammensatte verb, шв. löst sammansatta verb), а када се партикула јавља одвојено, иза глагола, такви глаголи се називају лабаво сложеним іллайлима (да. løst sammensatte verber, но. løst sammensatte verb, шв. löst sammansatta verb). У највећем броју случајева се глагол јавља у обе варијанте, често са одређеним степеном семантичке, прагматичке и стилске диференцијације (да. underskrive-skrive under, но. utgi-gi ut, шв. inlämna - lämna in) (уп. Bilandžija, 2017: 87-91). 
зика (пре свега француског). Они су препознатљиви као морфеме страног порекла и најчешће се комбинују са страним творбеним основама (Leira 1992: 18-19). Када се говори о позајмљивању творбених елемената из сродних језика као што је у овом случају немачки, ситуација се усложњава тиме што због сродности језика није увек једноставно недвосмислено разграничити домаћи од страног творбеног елемента.

Као прво, постоји одређени број когнатних облика, дакле творбених морфема које имају заједничко порекло. Тако међу продуктивним домаћим, скандинавским суфиксима и префиксима постоје они који имају своје корелате у другим германским језицима, уп. да. -skab, но/шв. -skap према нем. -schaft и енг. -ship; да/но. -dom/-dømmе и шв. -dom/-dömе према нем. -tum и енгл. -dom; да/но/шв. -lig према нем. -lich и енг. -ly; да/но. u- и шв. $o$ - према нем. и енг. un- или пак да/но. mis- и шв. miss- према нем. missи енг. mis- и слично (уп. и Liljestrand, 1975: 47; Thorell, 1981: 91).

Као друго, уколико је степен позајмљивања и на плану лексичког материјала између два сродна језика иначе висок, из синхронијске перспективе може бити тешко разграничити када је лексички материјал у коме постоји одређена деривациона морфема позајмљен у целости, а када се ради о домаћој творби речи помоћу позајмљене деривационе морфеме. Као што ћемо нешто ниже видети, у савременим скандинавским језицима постоје многе лексеме које садрже ненаглашене префиксе немачког порекла, а које су заправо као готове лексеме преузете из немачког језика. Такве лексеме је веома често немогуће разложити на структуру префикс + творбена основа, јер таква творбена основа у датом скандинавском језику не постоји. У том случају би лексему требало рачунати или као симплекс или као изведеницу чија је творбена основа уникатна морфема.

Као треће, а везано је за прва два, одређени творбени модел може бити подржан страним узором (Wessén, 1965: 66). На пример, иако су помињани суфикси -(n)ing, -skab/-skap или -lig суфикси домаћег порекла, и то веома продуктивни, то не значи нужно да међу данашњим именицама и придевима у којима се налазе нема оних који су настали према страном (првенствено немачком) узору. Овде се ради о својеврсном калкирању, при чему су одговарајући суфикси страног порекла замењени когнатним творбеним елементом: средњенисконемачко (у даљем тексту: снн.) -ing(e) и високонемачко (у даљем тексту: вн.) -ung > -ing (снн. woninge > да/но/шв. våning; снн. tidinge > шв. tidning); снн. -schop/-schap и вн. -schaft 
$>$-skab/-skap (на пример, снн. echtschop > да. aegteskab, но. ekteskap, шв. äktenskap; снн. ridderschap > да. ridderskab и но/шв. ridderskap), снн. -lik и вн. -lich > -lig (снн. muntlik> да. mundtlig, но/шв. muntlig; вн. beschwerlich $>$ да/но. besvaerlig, шв. besvärlig) (уп. и Liljestrand, 1975: 47). Слично и са префиксима: оно што су у почетку били префикси страног порекла који су се везивали за стране основе, с временом су почели да се везују и за домаће основе, али често подражавајући страни модел - да/но. forenkle и шв. förenkla (према вн. vereinfachen), да/но. forsvare и шв. försvara (према снн. vorantworden или вн. verantworten), уп. и снн. behelplik> да. behjoelpelig, но. behjelpelig, шв. behjälplig (у вези са архаизмом behjoelpel behjelpe/behjälpa $<$ снн. behelpen).

\section{2 Немачко порекло префикса - нисконемачки и високонемачки}

Када се каже да су ово префикси немачког порекла, важно је напоменути да се овде превасходно ради о префиксима који су у скандинавске језике дошли из нисконемачког језика у периоду средњег века. То су данашњи скандинавски префикси be-, bi-, for-/för-, unn-/und- и veder-. Утицај који је среgњенисконемачки (да. middelnedertysk, но. mellomnedertysk, шв. medellågtyska) извршио на скандинавске језике од почетка 13. до краја 15. века не може се мерити ни са огромним утицајем који у последњих 60 година врши енглески језик.

Утицај средњенисконемачког језика везује се за политички, економски и културни утицај Ханзе/Ханзеайске лиіе, савеза немачких градова окупљених око Либека. Немачки трговци су оснивали своје ханзе/удружења у другим градовима ${ }^{4}$, а Ханза је убрзо по свом осни-

4 Једини скандинавски град који је учествовао као пуноправни члан лиге био је Висби на Готланду, док је Берген на западу Норвешке био један од градова са сопственом великом ханзеатском канцеларијом (Hansakontor). У граду је живела колонија од преко 3000 Немаца, што није занемарљив број ако се узме у обзир то да је Берген у периоду касног средњег века био једно време највећи нордијски град са десетак хиљада становника. Осим ових градова, и други скандинавски градови су повремено бивали чланови Ханзе, попут Стокхолма и Калмара, а одређени број немачких грађана населио се у Ослу, Тенсбергу, Копенхагену и Фалстербоу. Немачки трговци су се најдуже задржали у Бергену, где је директни контакт трајао преко 500 година и опстао је дуго после распада саме Ханзеатске лиге (канцеларија је била отворена од 1360. до1754. године). 
вању постала центар трговине на Балтику. Утицај је посебно видљив у тзв. централном добу Ханзе, током 14. и 15. века. О Ханзи се може говорити не само као о конфедерацији градова, већ и као великој економској и политичкој сили. У Скандинавији су моћни и богати трговци, уз подршку нових, великих бродова и наоружане пратње стицали економску моћ и високе положаје у градској управи (на пример, први познати градоначелник Стокхолма је био Немац, 1297. г.). Ханза је у то време, када се стабилизовала краљевска власт, утицала на развој класног друштва по утицају на континент, а ницање и развој градова у Скандинавији непобитно су подстакнути управо немачком трговачком експанзијом. Осим тога, немачки трговци утицали су на реструктурирање трговине укидањем робне размене и организовањем развијеног система продаје, складиштења и дистрибуције. У том периоду нисконемачки функционише и као језик-посредник за романске и класичне позајмљенице.

Утицај се првенствено огледа у сфери лексике, где аутори веома често процењују да је реч и до 50\% вокабулара, а свакако је реч о аgайиираним позајмљеницама које су веома фреквентне у општем фонду речи сва три језика (Bilandžija, 2015: 28). Оне се у скандинавистичкој лексикологији посматрају као позајмљенице (да. låneord, но/ шв. lånord), а не као туђице (да/но. fremmedord, шв. främmande ord). Лексеме које потичу из средњенисконемачког чине, дакле, према скандинавистима слој тзв. домаће лексике (но. hjemlige ord, шв. inhemska ord), и са базичном, језгреном лексиком индоевропског, општегерманског и нордијског порекла представњају слој лексике коју изворни говорник није у стању да препозна као страни (Bilandžija, 2015: 29). Осим тога, средњенисконемачки језик је извршио суштински утицај на инвентар творбених морфема у скандинавским језицима. Инвентар творбених морфема нисконемачког порекла је посебно велик међу суфиксима, али је типолошки гледано посебно значајан утицај у сфери префиксације. За то постоје језичко-историјски разлози, које ћемо овде укратко објаснити.

Наиме, до времена када утицај средњенисконемачког постаје очигледан, скандинавски језици су у систему глаголске деривације већ били изгубили продуктивну префиксацију (Seip 1955: 23, 45, 2015; Wessén, 1965: 110; Bandle et al, 2002: 736-737). У свим нордијским језицима су до краја 12. века глаголи већ били превасходно 
или суфигирани или сложени, а тек под утицајем снн. премодификација опет постаје продуктиван тип творбе. Који су били разлози овако велике промене у деривацији глагола? Разлог раног губитка префикса налазимо у периоду норgијске синкоие (но. synkopetiden), која траје од 6. века и која означава период прелаза из пранордијског периода ка периоду староскандинавских језика. Она је подразумевала губитак вокала у ненаглашеним слоговима, а резултат су, осим битно краћих речи, биле суштинске промене у флексији. Губитак ненаглашених вокала се дешавао првенствено у финалним позицијама (апокопа), што је утицало на наставке за облик код свих променљивих врста речи, па су скандинавски језици до краја средњег века полако изгубили падежне наставке у деклинацији, те наставке за лице и број у конјугацији. У систему префиксације су глаголи погођени и синкопом и аферезом, када су ненаглашени префикси или изгубили свој вокал или нестали у целости, можда још и на почетку периода синкопе (Seip, 1955: 23). У нордијским језицима је на тај начин у потпуности нестао општегермански префикс bi- (данашње be-). У викиншком периоду (9-11. век) је за старонорвешки језик посведочено да су се задржали префикси of-, um- и једним делом ga- (њихови продукти су у савременом језику лексикализовани, и ови стари префикси се више не распознају као творбене морфеме), те for- у деривацији именица и fyrir- (fyr-) у деривацији глагола (Seip, 1955: 205). Ови префикси су се задржали јер су били носиоци нагласка на првом слогу, уп. fyrirgefa (Næs, 1965: 366). У време јаког утицаја Ханзе, немачки префикси попуњавају празно место у систему помоћу когнатних облика старих префикса.

У периоду након реформације утицај нисконемачког више није доминантан, а међу лексичким позајмљеницама је видљив утицај високонемачкої језика. Овај утицај свакако није толико далекосежан као утицај средњенисконемачког у претходним вековима, али високонемачки све до II светског рата остаје важан језик-давалац. Утицај високонемачког језика заснива се на политичком, економском и културном утицају аристократије (посебно у Данској), на утицају који изазива ширење протестантских идеја, а потом и на утицају немачке књижевности и филозофије. На пољу творбе речи установљава се да су у овом пероду позајмљени немачки префикси $a n-, g e-$ и er-, који нису развили продуктивност попут нисконемачких префикса, а уплив лексема из- 
ведених префиксима be-, bei- и ver- додатно појачава већ установљени систем префиксације. За префиксе ge- и er- се не може установити посебно категоријално значење којим утичу на валентност и значење деривата, они се везују за ограничен број глаголских и именских лексема за које се зна да су у целини преузете из немачког језика. Значење деривата је лексикализовано. Префикс ge- се јавља скоро без изузетка као префикс именских речи (веома сличан инвентар у сва три језика), док међу лексемама изведеним помоћу префикса er- има доста глагола: да. gebommerlig, gebrokken, gebyr, geråde, gebis, gebet, geborde, gedigen, gehør, gelassen, geled, gelejde, geloender, gemak, gemal, gemen, gemyse, gemyt, gerere sig, gerigt, gesandt, gespenst, gesims, gevalt, gevind, gevar I erfare, erholde, erhverve, erindre, erobre, erkende, erkloere, erkyndige, ernore, erstatte; но. gebiss, gebrokken, gebet, gevor, gelender, gebyr, gehør, geberde, gedigen, gehalt, gelenk, gemakk, gemal, gemytt, geråde, gesandt, gesims / erindre, ernoere, erfare, erobre, erstatte, ergre, erlegge, erholde, erkjenne; шв. gebit, gedigen, gehäng, gehör, gemak, gemen, gemensam, gemyt, gemål, genast, gering, geschäft, gesims, gesäll / erbjuda, erfara, erfaren, erfordra, erhålla, erinra, erkänna, ersätta, erbarmlig.

\section{4. Ненаглашени префикси немачког порекла у савременим скандинавским језицима}

У овом одељку ће бити речи првенствено о глаголским изведеницама помоћу префикса be- и for-/för- с обзиром на известан степен синтаксичке и семантичке регуларности који се може установити. Ненаглашени префикси немачког порекла јесу константна тема уџбеника творбе речи у скандинавским језицима као и одређеног броја научних чланака, и постоје различити предлози класификације на основу синтаксичких, семантичких и (ређе) прагматичких параметара. Па ипак, у овим класификацијама постоје одређене мањкавости, а наша примарна примедба тиче се сложености класификација, нарочито када су значења деривата у питању. Аутори често врше исцрпне анализе са великим бројем супкласификација, при чему је веома често одређена супкласа илустрована помоћу једног или два примера. У неким случајевима се ради о творбеним основама које нису нордијског порекла, 
па остаје отворено питање да ли је у том случају уопште могуће дефинисати семантички однос који влада између префикса и творбене основе.

\section{1. Префикс be-}

Префикс $b e$ - се творби глагола у сва три скандинавска језика додаје на:

- глаголске творбене основе (у даљем тексту: ТО): на пример, да. bebo, beflyve, befragte; но. begå, beholde, besvare; шв. belägga, besjunga, betaga,

- именичке творбене основе: на пример, да. befugte, begrunde; но. bemanne, beskatte; шв. befolka, beediga, те

- придевске творбене основе; на пример, да. berigtige, но. bestyrke, шв. berika.

Када изводи глаголе од именских творбених основа, префикс $b e$ - ступа често у неку врсту префиксално-суфиксалне творбе, будући да се на именску творбену основу истовремено додају префикс $b e$ - и суфикс за извођење глагола: но. be-mann-e или шв. be-rik-a. Код свих типова творбених основа постоје одређени изазови у морфолошкој анализи, посебно код девербативних: (а) ТО може постојати у савременом скандинавском језику, али је изведеница настала преношењем страног обрасца и значења јер је и основа немачка позајмљеница (да. bearbejde, но. bearbeide, шв. bearbeta < нем. bearbeiten; да/но. beklage, шв. beklaga < снн. beklagen), (б) ТО може постојати у савременом скандинавском језику, али је изведеница настала као преводни еквивалент према немачком предлошку (шв. bedöma < нем. beurteilen; шв. besegra < нем. besiegen); (в) ТО је данас застарели глагол (шв. bebåda $<$ ст.шв. bebudha/bebodha), (г) ТО је вербална уникатна морфема (најчешће посведочена још у старијем језичком стању, али као адаптирана реч немачког порекла) (да. begynde, но. begynne < снн. beginnen, шв. bedröva < снн. bedröven, да. begcre, но. begjøre, шв. begära < снн. begeren). И код деноминалних глагола на $b e$ - први ниво анализе може показивати да је ТО именица или придев који у савременом језику постоји, иако је заправо реч о старим калковима: на пример, да. byrde 
'терет' : bebyrde 'оптеретити', заправо према нем. bebürden, шв. ed 'заклетва' : beediga 'заклети се', заправо према нем. beeidigen.

Уколико је ТО глаголска, главна одлика префикса $b e-$ и у немачком језику и у скандинавским језицима је синйаксичка (или синтаксичко-семантичка) моgификација у вези са различитим операцијама промене валентности (Söderbergh, 1971: 59; Elert, 1973: 112; Thorell, 1981: 66-68; Fleischer \& Barz, 1992: 320; SAG II: 524). У савременим скандинавским језицима су две најважније модификације ове врсте синтаксичка транзитивизација и локативна алтернација.

(a) Кад је у питању йранзийивизација, глагол у ТО је синтаксички непрелазан. Префигирани глагол је синтаксички прелазан и захтева конструкцију са директним објектом, уп. да. bo (i lejlighed) > bebo (en lejlighed), но. skyte (på fienden) > beskyte (fienden), шв. svara (på en fråga) > besvara (en fråga). Наглашавамо да се у овом контексту термин транзитивизација користи искључиво као синтаксичка транзитивизација, будући да се функција транзитивизације огледа у томе што се исти актант код непрефигираног глагола означава везаним адвербијалом ${ }^{5}$, док се код префигираног глагола кодира као директан објекат. Такви су још и глаголи: да. sejre (over nogen/noget) - besejre (nogen/noget), klage (over nogen/noget) - beklage (noget), grcede (over noget/nogen) - begrcede (noget/nogen); Ho. seire - beseire, kjempe (imot noe/noen) - bekjempe (noe/noen), glo (på noen) - beglo (noen); шв. segra (över ngn/ngt) - besegra (ngn/ngt), klaga (över ngt) - beklaga (ngt), додуше и са семантичком разликом, gråta (över ngt/ngn) - begråta (ngn), kämpa (mot ngn/ngt) - bekämpa (ngn/ngt).

(б) У скандинавистичкој литератури се друга најважнија трансформација најчешће помиње под називом objektsväxling (Thorell,

5 Термин везани аgвербијал (шв. bundet adverbial) користи се у новијој скандинавистичкој литератури да означи адвербијал у оквиру глаголске фразе који је обухваћен валентношћу глагола (SAG I: 159). Један тип везаног адвербијала је и тзв. objektliknande adverbial ('адвербијал налик објекту') којим се означава досадашњи ӣреgлошки објекай (да. propositionsobjekt, но. preposisjonsobjekt, шв. prepositionsobjekt) чији је статус у традиционалној граматици релативно нестабилан (понекад се схвата као врста индиректног објекта, понекад као посебна врста објекта). Примери оваквих конструкција су да. stole på nogen, но. tenke på noe, шв. skratta åt något. Глаголи са оваквим објектом се сматрају синтаксички непрелазним, али се нивоима њихове семантичке прелазности може посветити посебна студија која превазилази обиме овог рада. 
1981: 181) (уп. и термин Objektverschiebung код Fleischer \& Barz, 1992: 321). Овакав термин има нешто већу експланаторну вредност у немачком језику, који разликује падеже и сходно томе објекте у генитиву, дативу или акузативу, за разлику од савремених скандинавских језика код којих се директност објекта не може условити одређеним падежом. Овде је у скандинавским језицима реч о тзв. локайивној алиеернацији, која подразумева исказивање аргумента локације и аргумента теме (лоцираног објекта) на различите начине. На англофоном подручју позната је и под називом „spray-load alternation“. И глагол који се налази у ТО и префигирани глагол су синтаксички прелазни, и чине конструкцију са директним објектом. Код непрефи-

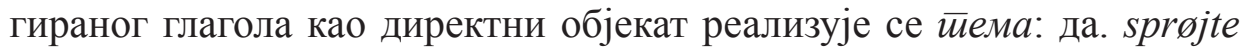
(pesticider), но. bygge (hus), шв. strö (pärlsocker), док се локација реализује као адвербијал: sprøjte (pesticider på afgrøder), bygge (hus på tomten), strö (pärlsocker över kakan). С друге стране, код префигираног глагола као директни објекат реализује локащија, а тема као адвербијал: да. besprøjte (afgrøder med pesticider), но. bebygge (tomten med hus), шв. beströ (kakan med pärlsocker). У наредним анализама би вредело поближе истражити и употребу партиципа перфекта ових глагола у атрибутивној функцији, јер примећујемо да се партицип перфекта непрефигираног глагола везује и за тему и за локацију (да. andre sprøjtede pesticider / sprøjtede landområder), док се партицип перфекта префигираног глагола појављује само уз локацију (да. besprøjtede landområder).

Када су у питању префигирани глаголи са именским ТО, осим очигледне синтаксичке транспозиције (придев/именица > глагол), обично се издвајају одређене семанииичке ирансформације. Две најважније семантичке трансформације деноминалних глагола са префиксом be- у савременим скандинавским језицима су каузативизација и орнативизација.

(а) Под каузайивизацијом овде подразумевамо трансформацију којом се од именских основа изводе глаголи са значењем „учинити каквим” или „учинити каквим у већој мери”. Такве су трансформације, на пример, да. rig > berige (уп. и парафразу 'gøre rig/rigere'), но. rolig > berolige, шв. styrka > bestyrka. Помоћу префикса be- изведен је 
одређени мањи број каузативних глагола, њихов број је у скандинавским језицима већ дуже време константан и префикс се више у овом значењу не сматра продуктивним (Bilandžija, 2014: 56).

(б) Под орнайивизацијом подразумевамо трансформацију којом се одређена величина именује према квалитету који поседује или који јој се придодаје, и према традицији можемо овај назив применити на све односе који подразумевају опремљеност (,,украшеност“6) чиме (поседовати нешто, бити нечим намазан / пресвучен / покривен / окружен и сл.). Помоћу префикса $b e$ - изведени су, на пример, следећи глаголи у орнативном значењу: да. befugte ('give noget fugtighed'), но. befolke, bekranse ('legge krans på monument/grav'), шв. bemanna ('förse med manskap') или неологизам betårta. Међу речима изведеним помоћу префикса be- постоји један број партиципа и квазипартиципа перфекта. Прави партиципи перфекта потичу или од глагола који у језику више не постоје, и њихово значење је лексикализовано (на пример, да. befippet, behjertet, befcengt, beføjet) или пак постоје у саииивном значењу ('у потпуности', 'до крајње мере') (да. befoerdet, beloest, berejst; но. begrodd, bereist, belest; шв. belevad, beläst, berest, bevandrad). Оно што је занимљиво у контексту орнативности јесте то што се на материјалу уочава велика група квазийарииицийа са орнаииивним значењем. Такви су партиципи попут да. bebrillet, behoengt, behåret, behandsket, bevinget (одговарајући примери постоје и у норвешком и у шведском језику). Ове речи се називају квазипартиципима јер садрже морфеме које маркирају партицип перфекта слабих глагола, али се додају на именске основе, а не на глаголске. Овакве лексеме се у шведској граматичкој литератури називају и $\bar{u} а р \bar{u} u$ ичииским йрияевима (ธ̌v. participiellt adjektiv, уп. Lundbladh, 1995: 269, 270), а чести су и међу придевима насталим комбинованом творбом (Bilandžija, 2017: 166). И за такве квазипартиципе је карактеристично значење поседовања какве особине у смислу неотуђивог поседа (да. barbenet, но. firfotet, шв. torrskodd).

\section{2 Префикс for-/för-}

Анализа лексема које садрже творбени елемент for- (да/но.) и för- (шв.) усложњена је чињеницом да се он често јавља и код 
именица и код глагола, да је некад наглашен а некад ненаглашен, те да је значење некад транспарентно, а некад не. Поставља се питање да ли се у свим тим случајевима ради о префиксу, или се у истом облику може јављати хомонимни творбени елемент. У скандинавистичкој дериватологији понекад ово остаје недоречено, а нарочито питање врсте творбе којој творенице са овим елементом припадају. Наш став је да треба уложити напор како би се што јасније разграничили случајеви префиксације помоћу префикса for-/för- и случајеви (периферног) слагања са одредбама for $_{2}$ - (у сва три језика), да/но. førи шв. för ${ }_{2}$, те да/но. føre- и шв. före-.

(a) Ови елементи се из морфолошке перспективе могу посматрати или као самосталне лексичке јединице (сродне су предлогу и прилогу for у данском и норвешком језику, одн. för у шведском) или као префиксоиди.

(б) Из семантичке перспективе се може издвојити важан критеријум: као одредбе, for-/för- и њихови аломорфи имају аутономну семантику, доприносе значењу целокупне творенице својим лексичким значењем: то су махом темпорална и локативна значења 'испред', 'пре' или 'унапред', за разлику од префикса for-/ för- који носи општије, категоријално значење (Bilandžija, 2017: 178). У скандинавским језицима ове одредбе учествују у слагању именица, придева и глагола (да. forstad, forhistorisk, forpremiere, forbage; но. forsete, fortrinn, forheng, forhånd; шв. förarm, förstad, försommar, förkultivera).

(в) Из фонолошке перспективе, а везано је за претходно, for-/förи њихови аломорфи су као одредбе у принципу найлашени. Питање нагласка свакако није одлучујуће, али јесте типична карактеристика оваквих сложеница. Није одлучујуће, јер се као наглашен може јавити и префикс for-/för- али тада примарно код именичких деривата насталих од глагола изведених помоћу ненаглашеног for-/för-(тип: но. for 'bruke > 'forbruk, for 'løpe > 'forløp). Исти овај префикс се релативно ретко јавља и као наглашен префикс код глаголских изведеница, али тада у случајевима да је ТО и сама мотивисана (уп. но. 'forutsette, 'forurolige; шв. 'förorsaka, förorätta), при чему одређени број изузетака и недоследност употребе додатно усложњавају анализу (Elert, 1973: 83; SAG II: 524). 
(г) Ни историјска перспектива нам не пружа увек јасније објашњење. Основно правило каже да, уколико је реч о елементима немачког порекла, ненаглашени префикс одговара снн. vor- и вн. ver-. Уколико се ради о наглашеном елементу, он по правилу одговара или домаћем предлогу/прилогу for-/för-(уп. тачку б), старом наглашеном префиксу fyrir-, те снн. vor/vör- и вн. vor-. Као што смо помињали у одељку 3.2, до времена снажног утицаја снн. језика, међу префиксима који су преживели период нордијске синкопе нашли су се наглашено for- (номинални префикс) и fyrir- (вербални префикс). Префикс fyrir- ce у старонорвешком и староисландском јављао и у краћем облику fir-/fyr, што је с временом довело до преклапања са префиксом за деривацију именица, те је ранији префикс for- почео да се употребљава и у деривацији деноминалних глагола, а касније и код глагола деривираних од других основа (Seip, 1955: 327; Beito, 1970: 110). Весен нас упућује на историјат аналошког повезивања пејоративног fra- (фреквентно значење префикса för- у савременом шведском језику) са предлогом for, и његовог стапања са firi- у старошведском језику (Wessén, 1965: 111). Слична је ситуација и у немачком језику, за који Флајшер и Барц наводе да данашњи префикс ver- представља резултат аналошког повезивања старих предлога faur, fra и fair, из чега и проистиче велик број различитих значења овог типа префигираних глагола у савременом језику (Fleischer \& Barz, 1992: 325).

И за префикс for-/för- важе, као за $b e-$, исти изазови анализе који се везују првенствено за постојање домаће, скандинавске ТО у односу на коју бисмо могли тумачити значење деривата. У неким случајевима се из синхронијске перспективе мора рећи да се префикс везује за уникатну ТО, а разлог треба тражити првенствено у преузимању и адаптацији лексеме као целине (да. forsømme, forlise; но. forderve, forlange; шв. förbarma, förlora).

Префикс for-/för- додаје се на:

- глаголске ТО, као на пример, у да. forscenke, forhandle; но. forbruke, fordrive; шв. förkasta, förneka,

- $\quad$ именичке ТО, као на пример, у да. forbene, fornikle; но. fordampe, forgrene; шв. försilvra, förgubba,

- $\quad$ придевске ТО, као на пример, у да. fordumme, formørke; но. forlenge, forsure; шв. förstora, förbilliga. 
Код именских ТО је у великом броју случајева, као и код префикса $b e$ - реч о префиксално-суфиксалној творби.

За разлику од префикса $b e-$, који има нешто диференциранију улогу у синтаксичком преобликовању, код префикса for-/för- може се издвојити неколико већих, првенствено семантичких супкласа, при чему се неке од њих могу посматрати искључиво са аспекта значења (на пример, резултативност) и из сродне перспективе типа глаголске ситуације, одн. лексичког аспекта или акционсарта (нем. Aktionsart; но. aksjonsart, да/шв. aktionsart).

Уколико је ТО глаголска, префигирани глаголи типично имају следећа значења:

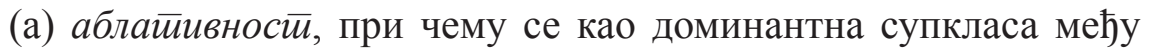
ТО јављају глаголи кретања. Међу префигираним глаголима у овој супкласи има и прелазних и непрелазних глагола. Такви су, на пример, да. forjage, fortrcenge, forsvinde; но. forgå, forsvinne, forflytte; шв. förkomma, fördriva, förtränga. Одговарајуће немачке глаголе Флајшер и Барц посматрају са нашим резултативним глаголима као подтип „перфективних глагола“ (Fleischer \& Barz, 1992: 326), а о ограничавању акционсарта говоре и аутори Грамайике Швеgске акаяемије наука (SAG II: 524).

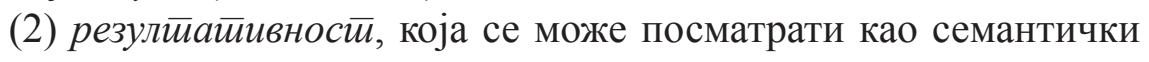
свршетак радње или као терминативно-резултативни акционсарт. Такви су следећи глаголи: да. forbløde, forbruge; но. forfryse, forbrenne, fortcere; шв. förbrinna, förbränna, fördunsta.

(3) инйензификација, која се везује с једне стране за терминативно-резултативни акционсарт, а са друге за извесну пејорацију с обзиром на то да глаголи означавају развој активности у штетном правцу, веома често као активност која се означава као погрешна или претерана. Међу овим глаголима се често јављају повратни глаголи. У ову супкласу убрајамо да. forvride, forregne sig, forhaste sig; но. forkjøle, forfalle, forsove seg, forspise seg; шв. förvränga, föräta sig, förläsa sig, försäga sig.

Префиксација помоћу префикса for-/för- сматра се нешто регуларнијом и продуктивнијом уколико је ТО нека именска реч. У том случају се као и код префикса be- посебно издвајају каузативизација и орнативизација. 
(1) Од именичких и придевских основа се у сва три језика изводе каузативни глаголи у значењу „учинити каквим“ или „довести у стање“, а тип творбе је продуктивнији него код префикса be-. Извођење каузативних глагола од именских ТО се у германистичкој литератури традиционално не препознаје као деривација каузативних,

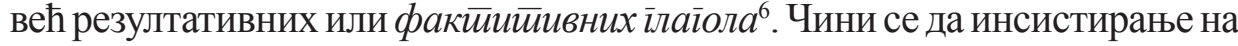
терминолошком разликовању у знатној мери доприноси запостављању овог релативно продуктивног смера деривације. Сматрамо да нема семантичких рестрикција које би онемогућиле да се овај тип творбе сматра творбом каузативних глагола; придеви су типични резултати, а деадјективали су типично каузативни (уп. Wunderlich 1997: 58). Такви су глаголи, на пример, да. forkulle, forenkle, forbene, forstøve, forny, forstørre, formindske; но. forskjønne, fordanske, forverre, fordype, forkorte, fortrolle, forkalke; шв. förstena, fördjupa, förfalska, förkorta, förmörka, försämra.

(2) Орнативност се у овом случају везује првенствено за опремање предмета/површине неким металом, за разлику од префикса be-, који се чешће везује за ТО које означавају делове тела и делове одеће: да. fornikle, forzinke, fortinne; но. forgylle, forsølve, fornikle; шв. förgylla, förkroma, förzinka (уп. Söderbergh, 1971: 49).

\section{5. Закључак}

Инвентар префикса немачког порекла у скандинавским језицима није занемарљив, нарочито у систему глаголске префиксације. Међу њима најзначајније место заузимају префикси be- и for-/för-, који показују известан степен фонолошке, морфолошке, синтаксичке и семантичкерегуларности. Осталипрефикси немачког пореклапоказују мањи степен фреквентности, и често се не могу издвојити посебни семантички и синтаксички обрасци који владају између творенице и творбене основе. Префикси немачког порекла у скандинавским

6 УП. и разликовање термина Faktitiva (Bewirkungsverben) и Kausativa (Veranlassungsverben) (Duden 1995: 462, 464). У норвешким граматикама се термин фактитив у овом значењу помиње само код старијих граматичара (уп. Heggstad 1975: 76), где се каузативни глагол посматра као нужно двоагентиван, и могућа је само парафраза „натерати неког да нешто уради“, што свакако искључује деадјективале, са значењем „довести нешто у неко стање“. 
језицима углавном кореспондирају са класом немачких нераздвојних префикса, а анализа семантичке и синтаксичке модификације је показала веома велике сличности у понашању наведених префикса у немачком језику и у скандинавским језицима. Ипак, већи број префигираних глагола остаје ван оквира могуће анализе јер се не могу једнозначно рашчланити на префикс и творбену основу најчешћи разлог су адаптација префигираног глагола у целини или калкирање страног предлошка помоћу когнатних облика, при чему се губи мотивисаност интерпретације. Немачки узор је увек близу, и по питању форме и по питању значења.

У случају да између префигираног глагола и глагола у ТО не постоји значајнији степен синтаксичке и семантичке модификације, уочава се да разлика између префигираног глагола и глагола у ТО може бити стилског карактера. Један члан пара је често конотативно маркиран, и то у смислу стилске маркираности. Префигиран глагол се може везивати за писани језик, формални или свечани стил, или је облик архаичнији у односу на непрефигиран глагол (уп. да. bedcekkedoekke, beflyve - flyve, но. befatte - fatte; шв. besmitta - smitta, förhjälpa - hjälpa).

\section{Литература}

Bandle, O. et al. (2002). The Nordic Languages. An International Handbook of the History

of the North Germanic Languages, Vol. 1. Berlin / New York: Walter de Gruyter [Handbooks of linguistics and communication science, v. 22.1]

Beito, O. T. (1970). Nynorsk grammatikk. Lyd- og ordlcere. Oslo: Det Norske Samlaget.

Bilandžija, S. (2014). Semantika kauzativnih konstrukcija u norveškom i srpskom jeziku (neobjavljena doktorska disertacija). Beograd: Filološki fakultet.

Bilandžija, S. (2015). O jednom sloju leksičkih pozajmljenica i uticaju nemačkog na skandinavske jezike. Prevodilac, 73, 27-34.

Bilandžija, S. (2017). Slaganje u skandinavskim jezicima - prototip i periferija. Beograd: FOKUS - Forum za interkulturnu komunikaciju.

Duden (1995). Duden: Grammatik der deutschen Gegenwartssprache. Mannheim et al.: Dudenverlag.

Duden (2006). Duden: Die Grammatik. Mannheim et al.: Dudenverlag. 
Elert, C.-C. (1973). Avledningar med förstavelserna be- och för- i svenskan. Med synpunkter på avledningars behandling i en generativ grammatik. Y: Svenska studier från runtid till nutid: tillägnade Carl Ivar Ståhle på 60-årsdagen den 27 juni 1973 (c. 107-133). Stockholm : Esselte studium.

Fleischer, W. \& Barz, I. (1992). Wortbildung der deutschen Gegenwartssprache. Tübingen: Max Niemeyer Verlag.

Kostić-Tomović, J. (2013). Tvorba reči u savremenom nemačkom jeziku. Beograd: FOKUS - Forum za interkulturnu komunikaciju. dostupno na:

http://www.komunikacijaikultura.org?Ebooks.html

Leira, V. (1992). Ordlaging og ordelement i norsk. Oslo: Det Norske Samlaget.

Liljestrand, B. (1975). Så bildas orden. Lund: Studentlitteratur.

Lundbladh, C.-E. (1995). Avledningar i Svenska Akademiens ordbok. Y: Svavarsdóttir, A. et al. (yp.), Nordiske studier i leksikografi 3. Rapport fra Konferanse om leksikografi i Norden Reykjavik 7.-10. juni 1995 (c. 265273). Reykjavik: Nordisk forening for leksikografi.

Næs, O. (1965). Norsk grammatikk. Elementoere strukturer og syntaks. Oslo: Fabritius \& sønners forlag.

SAG: Teleman, U. et al. (1999). Svenska Akademiens grammatik I-IV. Stockholm: Svenska Akademien.

Seip, D. A. ( $\left.{ }^{2} 1955\right)$. Norsk språkhistorie til omkring 1370. Oslo: H. Aschehoug \& Co.

Söderbergh, R. ( $\left.{ }^{2} 1971\right)$. Svensk ordbildning. Stockholm: Läromedelsförlagen.

Thorell, O. (1981). Svensk ordbildningslära. Stockholm: Esselte studium.

Wessén, E. ( $\left.{ }^{8} 1968\right)$. Svensk språkhistoria I: Ljudlära och ordböjningslära. Stockholm: Almquist \& Wiksell.

Wunderlich, D. (1997). Cause and the Structure of Verbs. Linguistic Inquiry, 28 (1), 27-68. dostupno na: http://www.jstor.org/stable/4178964

\section{Извори}

Den Danske Ordbog. dostupno na: http://ordnet.dk/ddo

Nationalencyklopedins ordbok (2004). Höganäs: Bokförlaget Bra Böcker.

Bokmålsordboka (revidert nettutgave 2016). dostupno na: ordbok. uib.no

Svenska Akademiens ordlista // Svenska Akademiens ordbok // Svensk ordbok utgiven av Svenska Akademien - sva tri dostupna na: https://svenska.se/ 
Sofija Bilandžija

Jelena Kostić-Tomović

\section{Summary \\ GERMAN PREFIXES IN CONTEMPORARY SCANDINAVIAN LANGUAGES}

This paper deals with unstressed prefixes of German origin within the system of verbal word-formation in contemporary Danish, Norwegian and Swedish. The focus of our analysis are the prefixes be- and for-/för-, although the inventory of German prefixes comprises of a larger number of prefixes (an-, bi-, unn-/und-, veder-, ge, er-). The authors investigate the origins of the prefixes (Low German vs. High German) and explain the underlying political, economical and sociocultural causes of the pervasive influence that the Hanseatic League and its merchants had had on Scandinavian societies and languages. An important aspect of this paper is the analysis of how one can differentiate between Nordic and German affixes, considering the degree of genetic similarity between the languages. The authors then investigate the status of the prefixes in Contemporary Scandinavian languages, considering the fact that they exhibit partial semantic and syntactic regularity, as well as limited productivity.

Key words: Scandinavian languages, German, prefix, word formation, lexicalization 